\title{
Transcriptional Activity of an Estrogen Receptor $\beta$ Subtype in the Medaka Oryzias dancena
}

\author{
Sejung Maeng ${ }^{1}$, Sung Woo Yoon ${ }^{1}$, Eun Jeong Kim ${ }^{2}$, Yoon Kwon $\mathrm{Nam}^{2}$, and ${ }^{\dagger}$ Young Chang Sohn $^{1}$ \\ ${ }^{1}$ Dept. of Marine Molecular Biosciences, Gangneung-Wonju National University, Gangneung 25457, Korea \\ ${ }^{2}$ Dept. of Marine Bio-Materials and Aquaculture, Pukyong National University, Busan 48513, Korea
}

\begin{abstract}
In vertebrate reproductive system, estrogen receptor (ER) plays a pivotal role in mediation of estrogenic signaling pathways. In the present study, we report the cDNA cloning, expression analysis, and transcriptional activity of ER $\beta 1$ subtype from medaka Oryzias dancena. The deduced O. dancena ER $\beta 1$ (odER $\beta 1 ; 519$ amino acids) contained six characteristic $\mathrm{A} / \mathrm{B}$ to $\mathrm{E} / \mathrm{F}$ domains with very short activation function 2 region (called AF2). A phylogenetic analysis indicated that odER $\beta 1$ was highly conserved among teleost ER $\beta 1$ subgroup. A conventional RT-PCR revealed that the odER $\beta 1$ transcripts were widely distributed in the multiple tissues, the ovary, brain, gill, intestine, kidney, and muscle. Further, the relatively higher $o d E R \beta 1$ expressions in the ovary and brain were clearly reproduced in RT-qPCR assay. When HA-fused odER $\beta 1$ expression vector was transfected into HEK293 cells, an immunoreactivity for odER $\beta 1$ was mainly detected in the nucleus part. Finally, an estrogen responsive element driven luciferase reporter assays demonstrated that the transcriptional activity of odER $\beta 1$ significantly increased by estradiol-17 $\beta$ (E2) in a dose dependent manner $(p<0.05)$. However, foldactivation of odER $\beta 1$ in the presence of E2 was markedly weak, when it compared with those of O. latipes ER $\beta 1$. Taken together, these data suggest that odER $\beta 1$ represents a functional variant of teleost ER $\beta$ subtype and provides a basic tool allowing future studies examining the function of $F$ domain of ER $\beta 1$ subtype and expanding our knowledge of ER $\beta$ evolution.
\end{abstract}

Key words : Estrogen receptor beta, Esr2a, Estradiol, Marine medaka

\section{INTRODUCTION}

The importance of the role of estrogens in the sexual development and reproduction of vertebrates is well known, and in particular, estrogens broadly contribute to regulation of female reproductive system, secondary sex characteristics during puberty, and ovulation (Rasier et al., 2006). Biosynthesis of estrogens appears to occur via the cytochrome P450 aromatase enzyme complex in diverse vertebrates, and it is generally accepted that estrogens are effectors for the reproduction strategy, such as implantation, pregnancy recognition, pregnancy maintenance, parturition, and lactation (Lange et al., 2002). Estradiol-17ß (E2) is an estrogen and the major female sex hormone involved in the regulation of the estrous and menstrual female reproductive cycles. The biological effects of E2 occur through binding with estrogen receptors (Ers; Evans, 1988).

ERs belong to the superfamily of nuclear receptors and specifically to the family of steroid hormone receptors that act as ligand-mediated transcription factors (Evans, 1988; Zhao et al., 2008). Two forms of the ER, ER $\alpha$, and ER $\beta$, have been characterized up to date. Both ER $\alpha$ and ER $\beta$

\footnotetext{
Manuscript received September 10, 2019, Received in revised form September 20, 2019, Accepted September 29, 2019

${ }^{\dagger}$ Corresponding Author : Young Chang Sohn, Ph.D., Dept. of Marine Molecular Biosciences, Gangneung-Wonju National University, Gangneung 25457, Korea. Tel: +82-33-640-2348, E-mail: ycsohn@gwnu.ac.kr
}

This is an Open Access article distributed under the terms of the Creative Commons Attribution Non-Commercial License (http:// creative-commons.org/licenses/by-nc/3.0) which permits unrestricted non-commercial use, distribution, and reproduction in any medium, provided the original work is properly cited. 
consist of distinctive domains, such as N-terminal transactivation domain, central DNA-binding domain (DBD), ligand-binding domain (LBD), and C-terminal coactivator/ corepressor interacting domain (Zhao et al., 2008). Although the biochemical responses of $\operatorname{ER} \alpha$ and $\operatorname{ER} \beta$ to estrogens are largely similar in their modes, the two ERs show different and specific gene expression pattern in some tissues such as breast cancer (Thomas \& Gustafsson, 2011; Haldosén et al., 2014).

In teleost fishes, ER $\alpha$ and $E R \beta$ are widely expressed in various tissues, and hepatic vitellogenesis which is a pivotal process for ovarian maturation provides a physiologically relevant endpoint of ER activation (Nelson \& Habibi, 2013). In fact, hepatic vitellogenesis and the $\mathrm{ER} \alpha$ gene expression are commonly used as bioassays for endocrine disruptors that have estrogen-like activity, whereas the biological significances of ER $\beta$ genes are not well elucidated up to now. Furthermore, involvement of ER $\beta$ in the control of estrogen-responsive genes in specific tissues is also poorly understood. In a previous report, E2-dependent induction of red fluorescent protein reporter gene expression driven by choriogenin $\mathrm{H}$ gene promoter was shown in transgenic marine medaka Oryzias dancena under a wide range of salinity conditions (Cho et al., 2013). To evaluate ER $\beta$-mediated E2 responsiveness in euryhaline teleosts, we firstly investigated the expression profile of $\operatorname{ER} \beta$ gene in several tissues and transcriptional activities of the ER $\beta$ proteins were examined in marine medaka.

\section{MATERIALS AND METHODS}

\section{1. cDNA cloning of $O$. dancena ER $\beta$}

Total RNA was extracted from the whole body of adult medaka $O$. dancena, using the RNA Prep kit (Bioneer, Daejeon, Korea) according to the manufacturer's protocol. To obtain full-length ER $\beta$ cDNA, the first-strand cDNA was synthesized with the extracted total RNA using a SMART rapid amplification of cDNA ends (RACE) cDNA
Amplification kit (Clontech Lab, Palo Alto, CA, USA). A cDNA fragment was amplified with a forward and reverse primer set (\#1 and \#2; Table 1) based on known O. latipes and $O$. javanicus ER $\beta$ cDNA sequences (GenBank Accession nos. NM_001104702 and AY917148). PCR amplification was performed in a final volume of $20 \mu \mathrm{L}$ containing $1 \mu \mathrm{g}$ of the marine medaka whole-body cDNA, $2.5 \mathrm{mM}$ dNTP $0.8 \mu \mathrm{L}, 10$ pmole of each oligo primer, $2 \times$ GC LA buffer $10 \mu \mathrm{L}, 5 \mathrm{U}$ LA Taq DNA polymerase (Takara Bio, Shiga, Japan). The reactions were carried out under the following cycling conditions: $5 \mathrm{~min}$ denaturation at $94^{\circ} \mathrm{C} ; 35$ cycles of $30 \mathrm{~s}$ at $94^{\circ} \mathrm{C}, 30 \mathrm{~s}$ at $50^{\circ} \mathrm{C}$, and $2 \mathrm{~min}$ at $72^{\circ} \mathrm{C}$; and $7 \mathrm{~min}$ at $72^{\circ} \mathrm{C}$. Full-length cDNAs for entire coding region of $O$. dancena ER $\beta$ (odER $\beta$ ) were obtained by RACE PCR amplification in a final volume of $25 \mu \mathrm{L}$ including $1 \mu \mathrm{g}$ of 3'- or 5'-cDNA template, 2 pmole of gene-specific primers (\#1 or \#2; Table 1) and the Universal Primer A Mix (\#3, Table 1), $10 \times$ Advantage 2 PCR buffer $2.5 \mu \mathrm{L}, 10 \mathrm{mM}$ dNTP mix $0.4 \mu \mathrm{L}$, and $50 \times$ advantage 2 polymerase mix (Clontech Lab) $0.4 \mu \mathrm{L}$ with the following cycles: $5 \mathrm{~min}$ denaturation at $94^{\circ} \mathrm{C} ; 5$ cycles of $30 \mathrm{~s}$ at $94^{\circ} \mathrm{C}$ and $3 \mathrm{~min}$ at $68^{\circ} \mathrm{C} ; 5$ cycles of $30 \mathrm{~s}$ at $94^{\circ} \mathrm{C}, 30 \mathrm{~s}$ at $66^{\circ} \mathrm{C}$, and $3 \mathrm{~min}$ at $72^{\circ} \mathrm{C} ; 25$ cycles of $30 \mathrm{~s}$ at $94^{\circ} \mathrm{C}, 30 \mathrm{~s}$ at $64^{\circ} \mathrm{C}$, and $3 \mathrm{~min}$ at $72^{\circ} \mathrm{C}$; and $7 \mathrm{~min}$ at $72^{\circ} \mathrm{C}$. The amplified PCR products were cloned into pGEM-T Easy vector (Promega, Madison, WI, USA). To construct the odER $\beta$ expression vector, open reading frame of the odER $\beta$ cDNA was amplified by a conventional PCR using a primer set (\#4 and \#5, Table 1) and cloned into the Eco RI-Xho I restriction sites in pcDNA3-HA-NLS vector (Zavacki et al., 1997). Escherichia coli competent cells were transformed with the vectors and all of the constructs were sequenced by the Sanger method.

\section{Phylogenetic and sequence analysis of $O$. dancena ERß1 cDNA}

The amino acid alignment was carried out by CLUSTALW with MEGA6 (Tamura et al., 2013), and the phylogenetic tree was constructed using the maximum-likelihood (ML) 
Table 1. Oligo primers used in the polymerase chain reactions

\begin{tabular}{ccccc}
\hline \hline Target & Primer & Direction & Sequence $\left(5^{\prime} \rightarrow 3^{\prime}\right)$ & Application \\
\hline odER $\beta 1$ & $\# 1$ & Sense & GCAATGGGAACCACTTTGGACTC & Partial cDNA cloning \\
odER $\beta 1$ & $\# 2$ & Antisense & GATGTGAGCGTCCAGCATCTC & Partial cDNA cloning \\
odER $\beta 1$ & $\# 3$ & $\begin{array}{c}\text { Sense/ } \\
\text { antisense }\end{array}$ & CTAATACGACTCACTATAGGGCAAGCA & RACE PCR \\
odER $\beta 1$ & $\# 4$ & Sense & GCGAATTCATGGGAACCACTTTGGACT & Plasmid construction \\
& & & CAGAG & \\
odER $\beta 1$ & $\# 5$ & Antisense & GCCTCGAGTCAACGCAGAGTGGCCATT & Plasmid construction \\
$18 S r R N A$ & $\# 6$ & Antisense & ACGG & Reverse transcription \\
odER $\beta 1$ & $\# 7$ & Sense & TCCAAGCTGCTCAGCATTCA & RT-qPCR \\
odER $\beta 1$ & $\# 8$ & Antisense & TCTGTTCCTGCAGACAAAGG & RT-qPCR \\
$18 S r R N A$ & $\# 9$ & Sense & TCCAGCTCCAATAGCGTATC & RT-qPCR \\
$18 S r R N A$ & $\# 10$ & Antisense & AGAACCGGAGTCCTATTCCA & RT-qPCR \\
\hline
\end{tabular}

Underlined sequences indicate restriction enzyme recognition sites.

RACE, rapid amplification of cDNA ends.

method based on the JTT matrix-based model (Jones et al., 1992). Branch supports were provided using 1,000 bootstrap replicates.

\section{Tissue distribution assay of $O$. dancena ER $\beta 1$} transcripts

To examine tissue distribution pattern of ER $\beta 1$ transcripts, 12 kinds of tissues including brain, eye, fin, gill, heart, intestine, kidney, liver, muscle, spleen, ovary, and testis were surgically removed from mature marine medaka individuals (six males and six females; average body weight $=2.3 \pm 0.3 \mathrm{~g}$ ) that had been communally grown under the culture conditions: salinity at $15 \mathrm{ppt}$, temperature at $26 \pm 1{ }^{\circ} \mathrm{C}$ and dissolved oxygen level at $6 \pm 1 \mathrm{ppm}$. Total RNA was extracted with Trizol reagent (Ambion, Thermo Fisher Scientific, Waltham, MA, USA) according to the manufacturer's instruction and further purified with RNeasy Plus Mini Kit (Qiagen, Hilden, Germany) including the DNase I treatment step. Integrity and purity of total
RNA sample was verified with $28 \mathrm{~S}: 18 \mathrm{~S}$ rRNA ratio on formaldehyde/MOPS agarose gel and OD260/280 nm $(260 / 230 \mathrm{~nm})$ spectrophotometry, respectively. For endpoint RT-PCR, equal amount of total RNA $(1 \mu \mathrm{g})$ from each individual tissue was pooled within a tissue type, and an aliquot $(2 \mu \mathrm{g})$ of the pooled RNA sample was reverse transcribed to cDNA using Omniscript RT kit (Qiagen) with oligo- $\mathrm{dT}_{20}$ priming method according to the manufacturer's protocol. In order to prepare a normalized control (18S rRNA; GenBank accession number HM347347), an $O$. dancena $18 \mathrm{~S}$ rRNA reverse primer (\#6, Table 1) was also included in the RT reaction as described previously. RT product was 8-fold (for ER $\beta 1$ ) or 20-fold (for $18 \mathrm{~S}$ rRNA) diluted with sterile water, and $2 \mu \mathrm{L}$ of diluted cDNA was used as template for each PCR reaction. Endpoint RT-PCR was carried with a pair of primer (\#7 and \#8; Table 1) to amplify a 240-bp odER $\beta 1$ cDNA fragment. Thermal cycling conditions are 33 cycles of $94^{\circ} \mathrm{C}$ for $20 \mathrm{~s}$, $58^{\circ} \mathrm{C}$ for $20 \mathrm{~s}$ and $72^{\circ} \mathrm{C}$ for $20 \mathrm{~s}$ with an initial denaturation 
step at $94^{\circ} \mathrm{C}$ for $2 \mathrm{~min}$. From each cDNA template, a 253 bp fragment of $18 \mathrm{~S}$ rRNA was also amplified as a normalization control with a pair of primer (\#9 and \#10; Table 1) under the same thermal cycling conditions described in Cho et al. (2011) except the reduction of cycle number to 22 . Amplified products $(5 \mu \mathrm{L})$ for both odER $\beta 1$ and 18S rRNA were electrophoresed on $2 \%$ agarose gels, and visualized with ethidium bromide (EtBr)-staining.

Based on the end-point RT-PCR assay, tissues examined to show the clear amplification of odER $\beta 1$ transcripts were selected for real-time quantitative RT-PCR (RT-qPCR). Basal expression levels of odER $\beta 1$ among those tissues were assayed with individual cDNA samples (three males and three females), and each cDNA template was assessed in triplicates. Oligonucleotide primers and thermal cycling conditions for odER $\beta 1$ and 18S rRNA were same as those used in end-point RT-PCR above, except the extension of the cycle number to 45 . PCR was conducted with LightCycler 480 SYBR Green I Master Mix and LightCycler 480 Real-Time PCR System (Roche Applied Sciences, Penzberg, Germany). PCR efficiencies of both primer pairs (i.e., for odER $\beta 1$ and $18 \mathrm{~S}$ rRNA) were 0.96 and 0.94 , respectively. Basal expression level of odER $\beta 1$ transcripts in each tissue was determined with $2^{-\Delta \mathrm{CT}}$ method based on the normalization against 18S rRNA level (Schmittgen \& Livak, 2008).

\section{Reporter assay}

HEK293 cells $\left(5 \times 10^{4}\right.$ cells/well $)$ were routinely cultured in Dulbecco's modified Eagle's medium (DMEM) supplemented with $10 \%$ fetal bovine serum (FBS, HyClone, GE Healthcare, Chicago, IL, USA) and 1\% antibioticantimycotic (Invitrogen, Grand Island, NY, USA) in a humidified atmosphere containing $5 \% \mathrm{CO}_{2}$ at $37^{\circ} \mathrm{C}$. The cells were seeded in 24-well plates and transfected with odER $\beta 1$, O. latipes ER $\beta 1$ (olER $\beta 1$ ), and masu salmon ER $\alpha$ $(\mathrm{msER} \alpha)$ expression vectors and reporter vectors including an estrogen-response element (ERE)-driven luciferase reporter (ERE-Luc) (Maeng et. al., 2005), and internal control vector for $\beta$-galactosidase (200 ng each) using Lipofectamine $^{\mathrm{TM}} 2000$ (Invitrogen). The olER $\beta$ expression vector was kindly provided by Dr. Yoshitaka Nagahama, National Institute for Basic Biology, Okazaki, Japan. After $3 \mathrm{hr}$ post-transfection, the cell medium was changed by DMEM with $10 \%$ charcoal-stripped FBS and $1 \%$ antibioticantimycotic. Detailed transfection, ligand treatment and luciferase assay were conducted as described previously (Maeng et al., 2005).

\section{Subcellular localization}

HEK293 cells were seeded on poly-D-lysine hydrobromide (Sigma-Aldrich, St. Louis, MO, USA)-coated coverslips and transiently transfected with HA-tagged ER expression vectors (200 ng each) as described before. After $30 \mathrm{~h}$, the cells were fixed for $10 \mathrm{~min}$ in $4 \%$ paraformaldehyde in PBS (Wako, Osaka, Japan) and further incubated for 10 min with PBS containing $0.1 \%$ Triton X-100. To block non-specific binding, the cells were incubated with $1 \%$ bovine serum albumin in PBST (PBS+ $0.1 \%$ Tween 20) for $30 \mathrm{~min}$ at room temperature. The cells were incubated with a 1:5,000 dilution of monoclonal anti-HA antibody produced in mouse (H9658, Sigma-Aldrich) in PBST overnight at $4^{\circ} \mathrm{C}$ in a humidified chamber. The cells were further incubated with a 1:2,000 dilution of anti-mouse $\operatorname{IgG}$ $(\mathrm{H}+\mathrm{L}), \mathrm{F}\left(\mathrm{ab}^{\prime}\right) 2$ Fragment (AlexaFluor 488 conjugate, Cell Signaling, Danvers, MA, USA) in PBST for $1 \mathrm{~h}$ at room temperature in the dark. The coverslips were mounted with Fluoroshield Mounting Medium with DAPI (Abcam, Cambridge, UK) and the cells were observed using a fluorescence microscope (Eclipse E200, Nikon, Tokyo, Japan). Fluorescence signals were not detected in the control cells incubated without the primary antibody.

\section{Statistical analysis}

Differences in basal mRNA expression levels of odER $\beta$ among adult tissues and luciferase activities 
determined with reporter assays for ERs were assessed with ANOVA followed by Duncan's multiple range test, while differences between sexes given a tissue type with Student's $t$-test. Difference was considered to be significant when $p<0.05$.

\section{RESULTS}

\section{Isolation of $O$. dancena ERß1 cDNA and se-} quence analysis

We cloned an ER $\beta 1$ cDNA from the whole body of adult marine medaka $O$. dancena based on $O$. latipes and $O$. javanicus ER $\beta$ cDNA sequences. The cDNA contained an open reading frame of 1,560 nucleotides encoding 519 amino acid residues. The overall protein sequence identities of the odER $\beta 1$ was relatively higher with ER $\beta 1$ subtype of O. latipes, Paralichthys olivaceus, and Oncorhynchus mykiss $(93.8 \%, 81.5 \%$, and $69.4 \%$, respectively), but relatively lower with ER $\beta 2$ and ER $\alpha$ subtypes of teleosts and human (44.1\%-57.0\%; Fig. 1A). Amino acid sequences of N-terminal $\mathrm{A} / \mathrm{B}$ and DNA binding $\mathrm{C}$ domains of odER $\beta 1$ were strikingly similar to those of olER $\beta 1(96.1 \%$ and $100 \%$ ), while the sequences of hinge $\mathrm{D}$ domain and ligand binding E/F domains of odER $\beta 1$ showed relatively lower similarities with the corresponding regions of olER $\beta 1$ ( $82.9 \%$ and $92.3 \%)$. The C-terminal amino acid sequence of odER $\beta 1$ was short when compared with those of olER $\beta 1$ and human ER $\beta$ (Fig. 1B). A molecular phylogenetic analysis revealed that teleostean ER $\beta 1$ proteins including odER $\beta 1$ formed a monophyletic group that was distinct from a clade comprising tetrapodian ER $\beta$ and teleostean ER $\beta 2$ and ER $\alpha$ proteins (Fig. 2).

\section{Tissue distribution pattern and basal expression} levels of $O$. dancena ER $\beta 1$ transcripts

From end-point RT-PCR analysis, odER $\beta 1$ mRNAs were predominantly expressed in the ovary (Fig. 3A). Besides the ovary, odER $\beta 1$ transcripts were also detectable in the brain, gill, intestine, kidney, and muscle, although expression levels in those tissues were significantly lower than that of the ovarian expression. Meanwhile, under the present RT-PCR conditions, odER $\beta 1$ mRNAs were not clearly detected in the eye, fin, heart, liver, spleen and testis. The robust expression of odER $\beta 1$ mRNAs in the ovary was clearly reproduced in RT-qPCR assay with female tissues, in which the ovarian expression level was 3.8-15.3 times greater than those in other tissues examined $(p<0.05$; Fig. 3B). Among non-ovarian tissues, brain showed a higher expression compared to other tissues $(p<0.05)$. Expression patterns in male somatic tissues were not significantly dissimilar from those observed in female. Like in female tissues, male brains displayed a relatively higher expression than others did, although the difference was not highlighted as much as in female (Fig. 3C). In comparison between genders within a given tissue, females tended to show a higher expression level of odER $\beta 1$ in the brain than males did, however, the difference was not statistically significant due to large individual variations. There was no gender-dependent difference in the expression level of the expression level of $o d E R \beta 1$ for gill, intestine, muscle and kidney $(p>0.05)$.

\section{Functional characterization of $O$. dancena $E R \beta 1$}

The transcriptional activity of the odER $\beta 1$ was evaluated by cotransfection of a luciferase reporter, ERE-Luc, into a mammalian cell line, HEK293. The ERE-Luc reporter activities of odER $\beta 1$ were significantly elevated by E2 and the response of odER $\beta 1$ showed a dose dependent manner $(p<0.05)$. The transcriptional fold-activation of odER $\beta 1$ in the presence of E2 was markedly weak, when the activities of O. latipes ER $\beta 1$ (olER $\beta 1$ ) and Oncorhynchus masou $\mathrm{ER} \alpha(\mathrm{msER} \alpha)$ were compared (Fig. 4B). The foldtransactivation of odER $\beta 1$ by E2 treatment showed a dose dependent manner. Transfected HA-tagged odER $\beta 1$, olER $\beta 1$, and $\operatorname{msER} \alpha$ expression vectors were mainly expressed in the nucleus of HEK293 cells (Fig. 4C). 
(A)

\section{Entire coding region}

Oryzias latipes ER $\beta 1$

Paralichthys olivaceus ER $\beta 1$

Oncorhynchus mykiss ER $\beta 1$

Oryzias latipes ER $\beta 2$

Paralichthys olivaceus ER $\beta 2$

Homo sapiens ER $\beta$

Oryzias latipes $\mathrm{ER} \alpha$

Oncorhynchus masou ER $\alpha$
$93.8(\%)$

81.5

69.4

53.4

57.0

50.9

43.9

44.1

amino acids

\begin{tabular}{|c|c|c|c|c|c|}
\hline $\begin{array}{c}\text { Oryzias dancena } \\
\text { ER } \beta 1\end{array}$ & $\mathrm{~A} / \mathrm{B}$ & & $D$ & $\mathrm{E} / \mathrm{F}$ & \\
\hline O. latipes ER $\beta 1$ & 96.1 & 100 & 82.9 & 92.3 & $(\%)$ \\
\hline P. olivaceus ER $\beta 1$ & 72.4 & 93.7 & 48.8 & 88.7 & \\
\hline O. mykiss ER $\beta 1$ & 42.1 & 93.7 & 31.7 & 84.6 & \\
\hline O. latipes $\mathrm{ER} \beta 2$ & 21.7 & 93.4 & 23.8 & 72.5 & \\
\hline P. olivaceus $\mathrm{ER} \beta 2$ & 25.3 & 94.7 & 21.4 & 72.5 & \\
\hline H. sapiens $\mathrm{ER} \beta$ & 13.2 & 89.9 & 17.9 & 63.2 & \\
\hline O. latipes $\mathrm{ER} \alpha$ & 13.2 & 86.1 & 14.6 & 56.3 & \\
\hline O. masou ER $\alpha$ & 15.8 & 84.8 & 19.5 & 56.3 & \\
\hline
\end{tabular}

(B)

o. dancena KGMDHLHCMK MKNVVPLYDL LLEMLDAHIP AVMATLR

o. latipes KGMDHLHCMK MKNMVPLYDL LLEMLDAHIM HSSRLPRQPP PQDAADPTET SAQGQRSCCD VSKAWTTSSA GTAEEPQKSD

H. sapiens KGMEHLLNMK CKNVVPVYDL LLEMLNAHVL RGCKSSITGS ECSPAEDSKS KEGSQNPQSQ

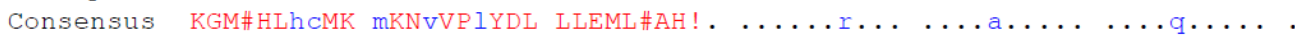

Fig. 1. Protein sequence identities of Oryzias dancena estrogen receptor (ER) $\beta 1$ subtype with teleost and human ER orthologs. (A) Identities for the entire coding region are represented at the upper lines. ERs typically contain six distinct domains termed $\mathrm{A}$ to $\mathrm{F}$ extending from the $\mathrm{N}$ - to $\mathrm{C}$-terminus. The four characteristic domains of the ER $\beta 1$ schematically represented with their corresponding identity percentages at the bottom lines. (B) Multiple sequence alignment of Oryzias ER $\beta 1$ and human ER $\beta$ C-terminal amino acids. Amino acids with $100 \%$ and $>60 \%$ conservation are shown in red and blue, respectively. The corresponding GenBank accession numbers for ER sequences are referred in the legend of Fig. 2.

\section{DISCUSSION}

In the present study, we cloned an ER $\beta 1$ subtype cDNA from $O$. dancena and examined the mRNA expression profile in various tissues. To date, two ER $\beta$ subtypes (ER $\beta 1$ and ER $\beta 2$ ) have been isolated from a variety of teleost fish species, including Japanese medaka and largemouth bass (Sabo-Attwood et al., 2004; Chakraborty et al., 2011), although a single ER $\beta$ gene was reported in mammals (Haldosén et al., 2014). The overall sequence identity analysis of three subtypes of ER indicated that odER $\beta 1$ is the ortholog of teleost ER $\beta 1$. This classification 


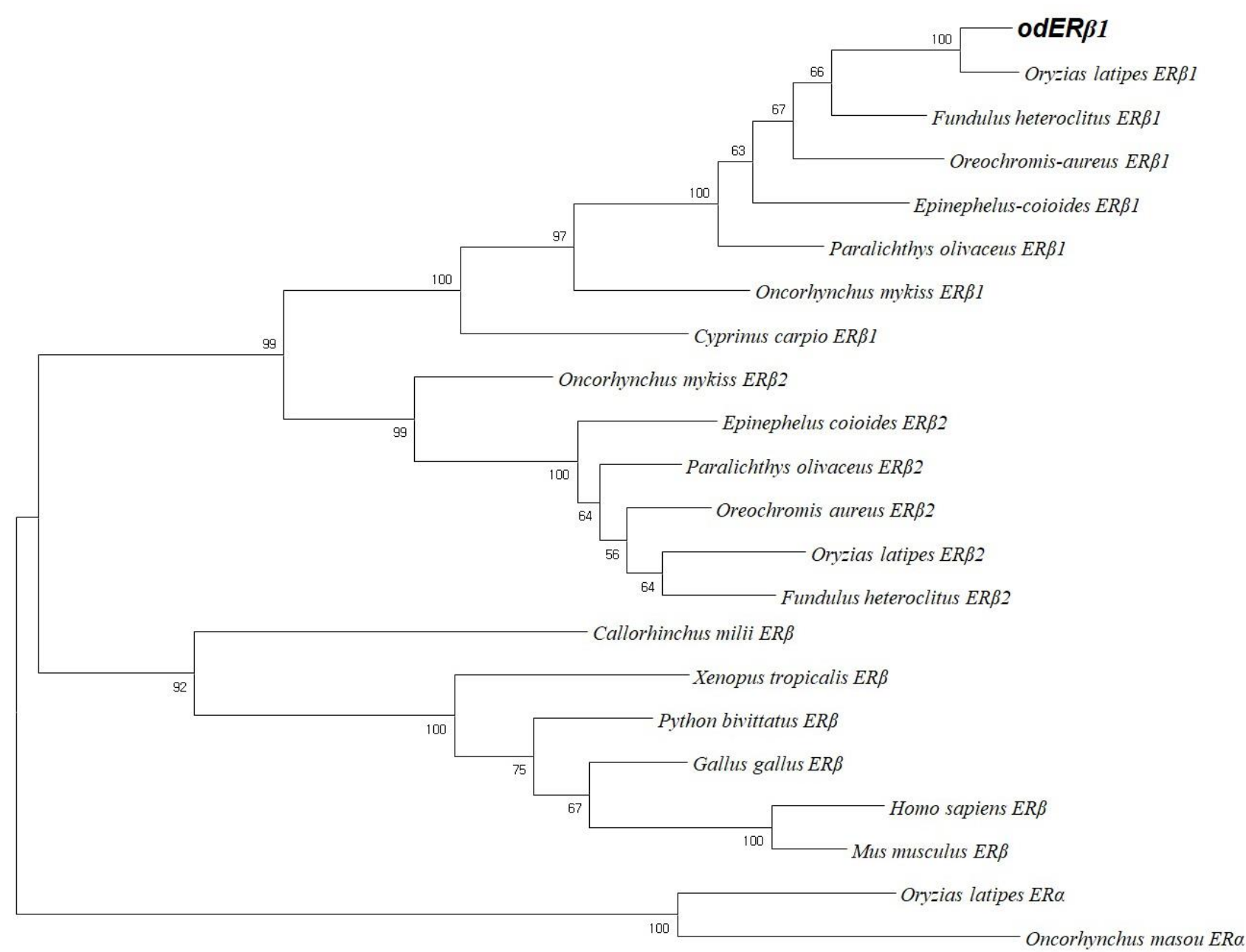

Fig. 2. Maximum-likelihood phylogenetic tree showing relationships between amino acid sequences of estrogen receptor (ER) subtypes. The bootstrap values from 1,000 replicates are given at each branch node. The scale bar indicates 0.1 amino acid replacements per site. GenBank accession numbers are as follows: ER $\beta 1$ subtype for Oryzias dancena (MN729292), O. latipes ER $\beta 1$ (NP_001098172), Paralichthys olivaceus (BAB85623), Oreochromis aureus (ACF75102), Fundulus heteroclitus (AAU44352), Epinephelus coioides (ADK90034), Cyprinus carpio (BAB91218), Oncorhynchus mykiss (P_001118225); ERß2 subtype for O. latipes (NP_001121984), O. aureus (ACF75103), F. heteroclitus (NP_001296906), P. olivaceus (XP_019961638), E. coioides (ADK90035), O. mykiss (NP_001118042); ER $\beta$ subtype for Callorhinchus milii (BAX07664), Python bivittatus (XP_007432491), Xenopus tropicalis (NP_001035101), Gallus gallus (NP_990125), Homo sapiens (CAA67555), Mus musculus (AAI41076); ER $\alpha$ subtype for O. latipes (P50241) and O. masou (AAS92970).

was supported by a phylogenetic analysis: ER $\beta 1$ and ER $\beta 2$ subtypes of teleost species and ER $\beta$ of tetrapods. The estimated amino acid length of odER $\beta 1$ were 519 which is shorter than olER $\beta 1$ (562 amino acids; Chakraborty et al., 2011) and human ER $\beta$ (530 amino acids; Ogawa et al.,
1998). The lacking of large portion of $F$ domain known as a hormone-dependent activation function AF-2 (Glass \& Rosenfeld, 2000) is the most different feature between odER $\beta 1$ and olER $\beta 1$. Taken together, odER $\beta 1$ is most likely a splicing variant of ER $\beta 1$ gene. In human, multiple 
(A)

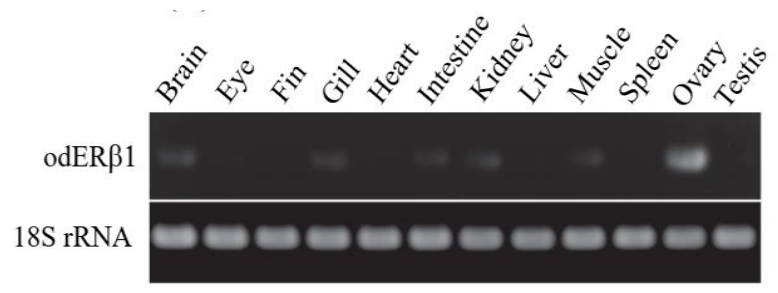

(B)

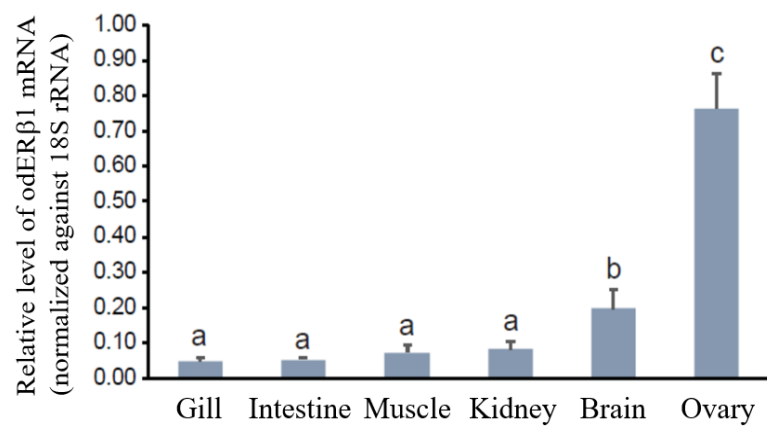

(C)

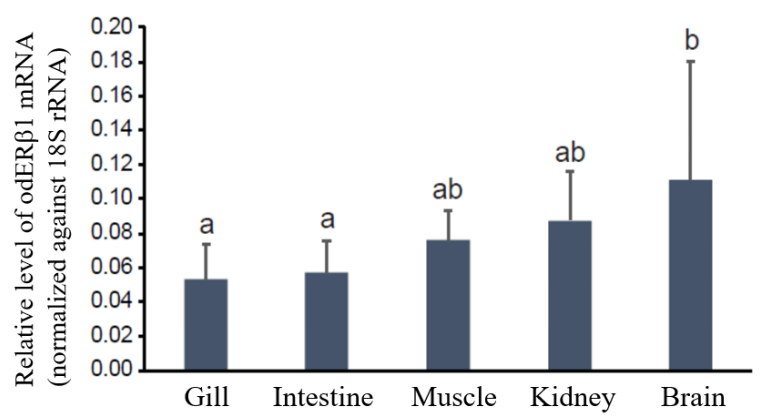

Fig. 3. Distribution and basal expression levels of ERß1 transcripts in tissues of mature Oryzias dancena. (A) Representative end-point RT-PCR gels to show the RT-PCR products of ER $\beta 1$ and 18S rRNA control. (B, C) Relative expression levels of ER $\beta 1$ mRNAs in tissues selected from females (B) or males (C) determined with RTqPCR assay based on the normalization against $18 \mathrm{~S}$ rRNA levels. Only tissues proven to show the clear expression of ER $\beta 1$ in the end-point RTPCR were subjected to RT-qPCR assay. Mean \pm SDs with different letters within a given gender $(a-c)$ are significantly different based on ANOVA followed by Duncan's multiple range test at $p<0.05$. ER, estrogen receptor.
ER $\beta$ isoforms lacking or changing of $F$ domain by alternative splicing of the last coding exons have been reported (Haldosén et al., 2014). The AF-2 region of E2-bound ERs mainly interact with transcriptional co-regulators, i.e., $\mathrm{N}$ CoR, SMRT, and GRIP1, and then the ER complex may recruit the basal transcription machinery including RNA polymerase II (Glass \& Rosenfeld, 2000; Webb et al., 2003). Although the function of AF-2 region of ER $\beta$ is unclear in teleosts, AF2-deleted female mice were significantly less preferred by adult males than that of normal females in odor preference tests (Antal et al., 2012). Implication of ER $\beta 1$ variants in the reproductive axis of teleosts is needed to be elucidated.

Tissue-specific expression of ER subtypes was demonstrated during the life cycle of teleosts (Sabo-Attwood et al., 2004; Chakraborty et al., 2011). The odER $\beta 1$ transcripts were strongly expressed in the ovary and significantly detectable in the brain than those of gill, intestine, kidney, and muscle, whereas olER $\beta 1$ mRNA expression was observed as faint bands in the testis and the brain (Chakraborty et al., 2011). In rainbow trout, the mRNA for ERß1 was detected in diverse tissues, e.g., the testis, ovary, brain, and kidney (Nagler et al., 2007). Interestingly, the rainbow trout ER $\beta 1$ transcript abundance in the ovary showed the highest expression at the beginning of the reproductive cycle, but then decreased afterward (Nagler et al., 2012). The expression of rockfish ER $\beta 1$ mRNA was also significantly higher in the ovary at the early-oocyte stage (Mu et al., 2013). The brain of female $O$. dancena showed relatively higher level of $o d E R \beta 1$ transcript than other tissues examined. Recently, $E R \beta 1$-null female medaka showed apparently normal sexual behavior, but without fertility and oviposition in response to male courtship (Kayo et al., 2019). These observations suggest that ERR1 expression may be important for estrogen signaling that starts the next cycle of ovarian development through brainpituitary-gonad axis in teleosts. In fact, expression of esr 1 (ER $\alpha$ gene), gnrhrl, $f_{s} h$, lh genes in the brain of red 
(A)

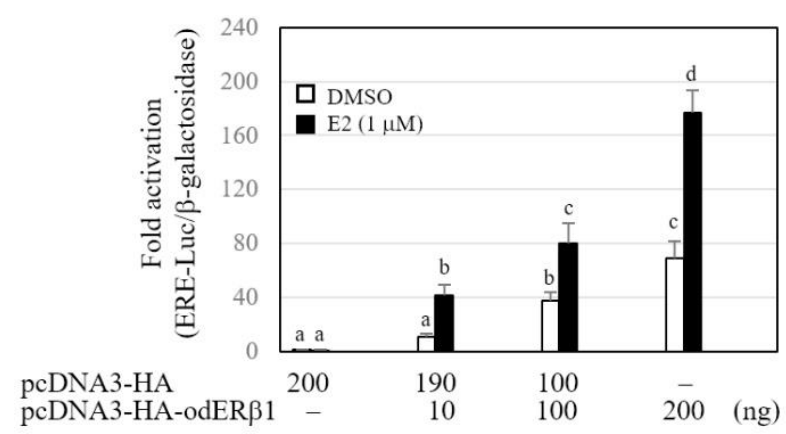

(B)

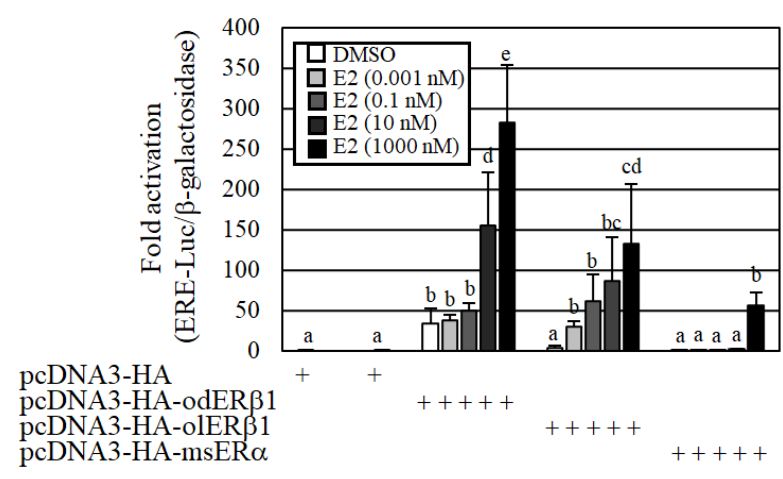

(C)

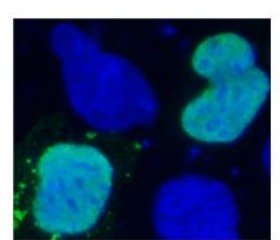

odER $\beta 1$

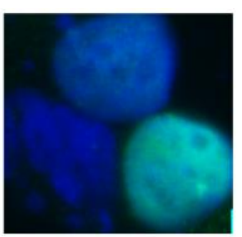

olER $\beta 1$

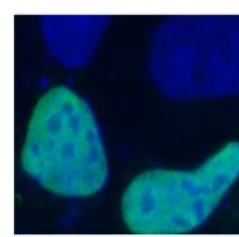

$\operatorname{msER} \alpha$

Fig. 4. Transcriptional activities and localization of Oryzias dancena ERß1 (odERß1) in HEK-293 cells. (A) Transcriptional activity of odER $\beta 1$ with estradiol-17ß (E2, $1 \mu \mathrm{M})$. HEK-293 cells were transfected with ERE-Luc reporter vector (200 ng) and $\beta$-galactosidase ( $\beta$-gal) expression vector $(100 \mathrm{ng})$, along with either pcDNA3-HA empty vector or odER $\beta 1$ expression vector as indicated. After $24 \mathrm{~h}$ of transfection, the cells were incubated in the presence of $1 \mu \mathrm{M}$ dosage of E2 or the same volume of DMSO for $18 \mathrm{~h}$. All cells were lysed and the luciferase activities were measured and normalized against the $\beta$-gal expression as an internal control. Values are the average of at least four transfections (mean \pm SD). (B) HEK-293 cells were transfected with expression vectors for odER $\beta 1$, O. latipes ER $\beta 1$ (olER $\beta 1$ ), or masu salmon ER $\alpha$ (msER $\alpha$ ) expression vector (200 ng each), together with ERE-Luc reporter vector and $\beta$-gal expression vector followed by treatment of E2 as indicated doses. Luciferase activity was measured $18 \mathrm{~h}$ after ligand addition and normalized as in (A). Mean \pm SDs with different letters are significantly different based on ANOVA followed by Duncan's multiple range test at $p<0.05$. (C) HEK-293 cells were transfected with HA-tagged odER $\beta 1$, olER $\beta 1$, and msER $\alpha$ expression vector (200 ng each) and the cells were fixed and examined by immunohistochemistry with anti-HA antibody and DAPI. Magnification $\times 1,000$. ER, estrogen receptor. 
spotted grouper was positively associated with the formation of ovarian cavity (Kim et al., 2016). More indepth investigations of individual tissues during different reproductive stages of medaka $O$. dancena will be required to better understand the biological significance of $E R \beta$ isoforms.

The transcriptional activities of odER $\beta 1$ were significantly elevated by $\mathrm{E} 2$ concentration dependent manner. In addition, the nuclear localization and the E2-dependent transactivation mode of odER $\beta 1$ were evidently demonstrated like those of olER $\beta 1$ and $\operatorname{msER} \alpha$. These results are similar to a previous report that three medaka ER subtypes including olER $\beta 1$ are capable of initiating transactivation of vitellogenin genes via upstream EREs (Lee Pow et al., 2016). The transcriptional activity of steroid hormone receptor superfamily including ERs is mainly dependent upon C-terminal ligand-binding $\mathrm{E} / \mathrm{F}$ domain and $\mathrm{AF}-2$ region (Glass \& Rosenfeld $\mathrm{MG}, 2000)$. When the amino acid sequence of odER $\beta 1$ was compared with those of olER $\beta 1$ and human $\operatorname{ER} \beta$, odER $\beta 1$ was estimated to be a splicing variant from ER $\beta 1$ gene that lacks $F$ domain and/or AF2 region. The olER $\beta 1$ having a long $\mathrm{F}$ domain showed higher fold-activation of transcription of EREdriven reporter gene in the presence of E2, whereas odER $\beta 1$ showed relatively weak fold-activation of the reporter gene in the presence of E2. These data indicate that the complete $\mathrm{F}$ domain and AF2 region are important for ligand binding and direct E2-dependent transcriptional activity of ER $\beta 1$. In fact, a mutant mammalian ER $\alpha$ deleted for the AF2 core domain impairs E2-induced transactivation by wild type ER $\alpha$ (Jung et al., 2001).

In summary, we cloned an $O$. dancena ER $\beta 1$ variant having a short $\mathrm{C}$-terminal activation function 2 region. The odER $\beta 1$ mRNAs were highly expressed in the ovary and brain. The transcriptional activity of odER $\beta 1$ increased by E2 in a dose dependent manner, although E2-dependent transactivation of odER $\beta 1$ was weaker than that of $O$. latipes ER $\beta 1$.

\section{ORCID}

\author{
Sejung Maeng \\ https://orcid.org/0000-0002-0730-0300 \\ Sung Woo Yoon \\ https://orcid.org/0000-0002-4104-9068 \\ Eun Jeong Kim \\ https://orcid.org/0000-0001-8303-1731 \\ Yoon Kwon Nam \\ https://orcid.org/0000-0001-8870-2098 \\ Young Chang Sohn \\ https://orcid.org/0000-0002-4140-2669
}

\section{AUTHOR CONTRIBUTIONS}

Conceptualization: Sohn YC.

Data curation: Maeng S, Yoon SW, Kim EJ.

Formal analysis: Nam YK, Sohn YC.

Methodology: Maeng S, Kim EJ.

Software: Maeng S, Yoon SW, Kim EJ.

Validation: Maeng S, Kim EJ.

Investigation: Maeng S, Yoon SW, Kim EJ.

Writing-original draft: Maeng S, Yoon SW, Kim EJ, Nam YK, Sohn YC.

Writing-review \& editing: Maeng S, Yoon SW, Kim EJ, Nam YK, Sohn YC.

\section{ETHICS APPROVAL}

Experiment with living marine medaka samples was approved by the Animal Care and Use Committee of Pukyong National University (Approved number 201816).

\section{REFERENCES}

Antal MC, Petit-Demoulière B, Meziane H, Chambon P, 
Krust A (2012) Estrogen dependent activation function of ER $\beta$ is essential for the sexual behavior of mouse females. Proc Natl Acad Sci USA 109:19822-19827.

Chakraborty T, Shibata Y, Zhou LY, Katsu Y, Iguchi T, Nagahama Y (2011) Differential expression of three estrogen receptor subtype mRNAs in gonads and liver from embryos to adults of the medaka, Oryzias latipes. Mol Cell Endocrinol 333:47-54.

Cho YS, Lee SY, Kim YK, Kim DS, Nam YK (2011) Functional ability of cytoskeletal $\beta$-actin regulator to drive constitutive and ubiquitous expression of a fluorescent reporter throughout the life cycle of transgenic marine medaka Oryzias dancena. Transgenic Res 20:1333-1355.

Cho YS, Kim DS, Nam YK (2013) Characterization of estrogen-responsive transgenic marine medaka Oryzias dancena germlines harboring red fluorescent protein gene under the control by endogenous choriogenin $\mathrm{H}$ promoter. Transgenic Res 22:501-517.

Evans RM (1988) The steroid and thyroid hormone receptor superfamily. Science 240:889-895.

Glass CK, Rosenfeld MG (2000) The coregulator exchange in transcriptional functions of nuclear receptors. Genes Dev 14:121-141.

Haldosén LA, Zhao C, Dahlman-Wright K (2014) Estrogen receptor beta in breast cancer. Mol Cell Endocrinol 382:665-672.

Jones DT, Taylor WR, Thornton JM (1992) The rapid generation of mutation data matrices from protein sequences. Comput Appl Biosci 8:275-282.

Jung DJ, Lee SK, Lee JW (2001) Agonist-dependent repression mediated by mutant estrogen receptor alpha that lacks the activation function 2 core domain. J Biol Chem 276:37280-37283.

Kayo D, Zempo B, Tomihara S, Oka Y, Kanda S (2019) Gene knockout analysis reveals essentiality of estrogen receptor $\beta 1$ (Esr2a) for female reproduction in medaka. Sci Rep 9:8868.
Kim HK, Kim JH, Baek HJ, Kwon JY (2016) Gene expression of aromatases, steroid receptor, $\mathrm{GnRH}$ and GTHs in the brain during the formation of ovarian cavity in red spotted grouper, Epinephelus akaara. Dev Reprod 20:367-377.

Lange IG, Hartel A, Meyer HHD (2002) Evolution of oestrogen functions in vertebrates. J Steroid Biochem Mol Biol 83:219-226.

Lee Pow CSD, Yost EE, Aday DD, Kullman SW (2016) Sharing the roles: An assessment of Japanese medaka estrogen receptors in vitellogenin induction. Environ Sci Technol 50:8886-8895.

Maeng S, Jung Y, Choi E, Jeon JK, Kim S, Gen K, Sohn YC (2005) Expression of gonadotropin subunit genes following 4-nonylphenol exposure in masu salmon: Effects on transcript levels and promoter activities via estrogen receptor alpha. Comp Biochem Physiol B Biochem Mol Biol 142:383-390.

Mu WJ, Wen HS, Shi D, Yang YP (2013) Molecular cloning and expression analysis of estrogen receptor betas (ER $\beta 1$ and ER $\beta 2)$ during gonad development in the Korean rockfish, Sebastes schlegeli. Gene 523:3949.

Nagler JJ, Cavileer T, Sullivan J, Cyr DG, Rexroad C (2007) The complete nuclear estrogen receptor family in the rainbow trout: Discovery of the novel ERalpha2 and both ERbeta isoforms. Gene 392:164-173.

Nagler JJ, Cavileer TD, Verducci JS, Schultz IR, Hook SE, Hayton WL (2012) Estrogen receptor mRNA expression patterns in the liver and ovary of female rainbow trout over a complete reproductive cycle. Gen Comp Endocrinol 178:556-561.

Nelson ER, Habibi HR (2013) Estrogen receptor function and regulation in fish and other vertebrates. Gen Comp Endocrinol 192:15-24.

Ogawa S, Inoue S, Watanabe T, Hiroi H, Orimo A, Hosoi T, Ouchi Y, Muramatsu M (1998) The complete primary structure of human estrogen receptor beta (hER beta) 
and its heterodimerization with ER alpha in vivo and in vitro. Biochem Biophys Res Commun 243:122-126.

Rasier G, Toppari J, Parent AS, Bourguignon JP (2006) Female sexual maturation and reproduction after prepubertal exposure to estrogens and endocrine disrupting chemicals: A review of rodent and human data. Mol Cell Endocrinol 254-255:187-201.

Sabo-Attwood T, Kroll KJ, Denslow ND (2004) Differential expression of largemouth bass (Micropterus salmoides) estrogen receptor isotypes alpha, beta, and gamma by estradiol. Mol Cell Endocrinol 218:107-118.

Schmittgen TD, Livak KJ (2008) Analyzing real-time PCR data by the comparative $\mathrm{C}(\mathrm{T})$ method. Nat Protoc 3:1101-1108.

Tamura K, Stecher G, Peterson D, Filipski A, Kumar S (2013) MEGA6: Molecular evolutionary genetics analysis version 6.0. Mol Biol Evol 30:2725-2729.

Thomas C, Gustafsson JA (2011) The different roles of ER subtypes in cancer biology and therapy. Nat Rev Cancer 11:597-608.

Webb P, Valentine C, Nguyen P, Price RH, Marimuthu A, West BL, Baxter JD, Kushner PJ (2003) ERbeta binds $\mathrm{N}-\mathrm{CoR}$ in the presence of estrogens via an LXXLLlike motif in the N-CoR C-terminus. Nucl Recept 1:4. Zavacki AM, Lehmann JM, Seol W, Willson TM, Kliewer SA, Moore DD (1997) Activation of the orphan receptor RIP14 by retinoids. Proc Natl Acad Sci USA 94:79097914.

Zhao C, Dahlman-Wright K, Gustafsson JA (2008) Estrogen receptor beta: An overview and update. Nucl Recept Signal 6:e003. 